\title{
"Elsevier inc. v. sci-hub": some aspects of copyright infringement in digital space
}

\author{
Mikhail Naumov ${ }^{* 1}$ \\ ${ }^{1}$ Volgograd Institute of Management, branch of the Russian Presidential Academy of National Economy and Public \\ Administration, 8, Gagarina Street, Volgograd, Russia, michael_naumov@mail.ru
}

\begin{abstract}
Many scientists are faced with the problem of finding the necessary scientific papers to use their work. In this regard, most of them resort to the opportunities provided by «scientific pirates». In connection with the digitalization of science, many scientists have the opportunity to download paid articles on specialized pirate sites. Such piracy activity is illegal and violates copyright. At the same time, neither legislation nor specific court orders can stop the illegal activities of such sites. In this article, using the example of one of the most famous copyright infringement case "Elsevier Inc. v. Sci-hub" conducted a comparative legal analysis of the copyright laws of the United States (a developed country) and Russia (a developing country), revealed weaknesses in the laws of both countries and concluded that the current state of copyright does not keep pace with the digitalization of science, and such inflexibility adversely affects not only the prestige of copyright itself, but also the research and investment climate in the state.
\end{abstract}

\section{Introduction}

Civil Code of the Russian Federation in Chapter 70 identifies three main objects protected by Russian copyright law, namely: works of science, literature, and art. Russian legislator widely uses this formulation to show the homogeneity of social relations formed around works of science, literature and art, as well as the absence of the need to differentiate these objects.

At the same time, it should be noted that in recent years, among all violations of copyright and related rights, the greatest public response was caused by a number of cases of copyright infringement of scientific works.

This situation is associated, first of all, with the fact that, despite the homogeneity of legal regulations and the similarity of the legal nature of objects of copyright, science and scientific works have exceptional social significance. Unlike literature and art, aimed primarily at satisfying recreational needs, science aims to obtain objective theoretical and practical information about reality. Scientific activity becomes especially significant in a postindustrial society, where knowledge becomes the most valuable resource for human activity, and access to it is greatly simplified due to the digitization of scientific information, the departure of science to the digital space.

The combination of massive storage capacity, powerful data manipulation techniques, and graphical capabilities has revolutionized both how basic research is conducted and how the resulting knowledge is preserved and disseminated in nearly all fields of science.

In this promising new research environment, scientists increasingly rely on automated knowledge discovery tools to mine and recombine vast amounts of data and literature that are flowing at rates that exceed the capacity of a single investigator to comprehend and manage [1].

In the early 2010s, the open science movement that proclaimed the need for «transparent and accessible knowledge that is shared and developed through collaborative networks» [2] began to gain in popularity.

However, supporters of this approach in practice face a serious legal barrier: copyright, which protects the interests of authors and copyright holders - mainly publishing houses. Bypassing such a barrier, copyright is violated, and scientific works are published and distributed in the open access. This phenomenon is called "scientific piracy".

\section{Problem Statement}

There is a trend according to which, with the advent of the digital space, more and more researchers, especially from developing countries, which include Russia, seek to obtain professional scientific knowledge through illegal downloading of scientific papers [3], that is, scientific piracy.

The current state of copyright, on the one hand, does not sufficiently protect the copyright and related rights of authors and copyright holders of scientific works, taking into account the digitalization of science, and on the

\footnotetext{
*Corresponding author: michael_naumov@mail.ru
} 
other hand, it generates unstable economic and emotional relations between copyright holders and scientists, which in turn creates a situation of negative perception of copyright among the scientific community.

A study of the recent judicial practice of copyright infringement in the digital space, the reaction of the authorities and the scientific community to it, as well as an analysis of the consequences, will sufficiently assess the relevance and flexibility of copyright through a comparative legal analysis of the copyright system in the United States (developed country) and Russia (developing country), as well as identifying the main practical and theoretical problems in the copyright system in both countries.

\section{Research Questions}

In this article, we will try to answer the question of whether the current state of copyright law in area of scientific researches in developed and developing countries makes it possible to protect the interests of right holders and society in modern conditions, due to the digitalization of science. Do existing legal norms meet current conditions and is there a need for a copyright reform?

\section{Purpose of the Study}

The purpose of this study is to analyze the fundamentals of American and Russian legislation in the field of copyright protection for scientific works for the subsequent identification of the features of the legal regulation of this area.

\section{Research Methods}

The research methodology in this study consist of common scientific methods of system analyse, dialectical and formal-logical methods and law science methods such as comparative legal method, formal legal methods.

\section{Findings}

In connection with the development and spreading of information technologies, especially through the telecommunications network "Internet", scientific piracy has acquired a new character: it has become more widespread and more effective.

Perhaps the most famous science pirate today is Alexandra Elbakyan, the founder of the Sci-Hub.org website, which provides open and free access to many scientific articles and publications. As noted by Science magazine, Sci-Hub downloaders live on every continent except Antarctica [4].

Sci-Hub activities, as well as a number of similar programs, caused massive discontent among scientific publishers, many of which filed lawsuits with the aim of restoring violated copyrights in court. Below, we invite you to read and analyze the most famous and resonant decision of the New York Southern District Court (District Court, Court) in the case of "Elsevier Inc." v. "Sci-Hub".

Despite the fact that the final decision in the case was made on June 21, 2017, most of the court's conclusions are contained in the decision on the opinion of preliminary injunction dated 10/28/2015.

The plaintiffs in the case were several companies which belong to the Reed Elsevier holding [5] - one of the largest publishing houses in the world. The defendants in the case were the Library Genesis project (a group of developers of scientific pirate sites), Scihub.org and the only real representative of the website Alexandra Elbakyan.

The essence of the claim was to take preliminary injunction to block these sites that violate Elsevier's copyright for further consideration of the case on the merits.

In its opinion, the court, referring to the case "WPIX Inc. vs. Ivi Inc." has previously indicated what conditions must be met for the application of preliminary injunction to protect copyright. In this case, the plaintiff must provide:

1) a likelihood of success on the merits,

2) irreparable harm in the absence of an injunction,

3) a balance of the hardships tipping in their favor,

4) that issuance of an injunction would not do a disservice to the public interest [6].

From the point of view of legal science, this position of the court can be called an evidentiary standard - a minimum set of factual information indicating the need to satisfy the claims of the plaintiff and make an appropriate decision. Russian procedural legislation (civil and arbitration), neither in terms of the protection of intellectual rights, nor in general, does not establish a clear standard of proof, providing the courts only with advisory and explanatory provisions specified in the decisions of the Plenums of the highest courts. Mandatory evidentiary standards are aimed at making judgments based on uniform measures, which makes them more predictable and standardized.

At the same time, these evidentiary criteria were borrowed by the District Court from the conclusions of the court decision, although in the same category of cases, but without taking into account the different legal, economic and social essence of these two cases, since the WPIX Inc. vs. Ivi Inc." related to copyright infringement for the broadcasting of television programs via an Internet platform. Actions of Ivi Inc. were of a commercially oriented nature, and also did not represent a significant public interest.

The relationship between Sci-hub.org and Elsevier clearly shows a different purpose of copyright infringement. In addition, Sci-hub.org's actions were not commercial in nature, and all funds received by the site are voluntary donations. Therefore, the application of uniform criteria for all cases of copyright infringement may lead to excessive formalism of the court proceedings and the desire of the court to resolve the issues known in advance, and not to analyze all the circumstances of the case. 
As for the directly motivational part, it begins with an analysis of the evidence provided by the plaintiff, necessary to indicate the likelihood of success in essence. Thus, the representatives of Elsevier pointed out the existence of a formal violation of the exclusive rights established by 17 U.S.C. $\S 106$. The court considered that in order to prevail on a claim for infringement of copyright, "two elements must be proven:

1)ownership of a valid copyright;

2)copying of constituent elements of the work that are original"[6].

This information was initially presented by the plaintiff to the court in the complaint and in more detail in the memorandum. They are based on a sequence of screenshots showing how a user could go to sci-hub.org, enter the necessary information (article title, DOI or URL), get a set of search results, follow the link to a copyrighted article on Science Direct via proxy server. In addition, the plaintiff also points to the post of A. Elbakyan on Twitter, indicating that "whenever an article is downloaded using this method, the Defendants save a copy of the article on their servers."

Interestingly that both American and Russian copyright law does not establish a list of admissible evidence. In accordance with the provisions of clause 55 of the Resolution of the Plenum of the Supreme Court of the Russian Federation No. 10 dated 04/23/2019, the evidence used in this case could well have been accepted by Russian courts.

So, admissible evidence is, including made and certified by the persons participating in the case, printouts of materials posted on the information and telecommunication network (screenshot), indicating the address of the Internet page from which the printout was made, as well as the exact time of its receipt. Such printouts are subject to assessment by the court when considering the case on an equal basis with other evidence [7].

It is also worth to be noting significant difference between American and Russian legislation. Thus, the District Court in its opinion directly obligates the plaintiff to prove the fact of copyright ownership and the fact of its violation. This imposition of the obligation on the plaintiff to prove his authorship and the fact of infringement of his copyright in the American judicial system was called "prima facie case".

"Prima facie" - a privileged position that serves as proof of the first or earliest appearance of the work, provided that the registration was made for a certain period ( 5 years) before or after its first use [8].

The use of a "prima facie case" is necessary in order to reduce the cases of unfounded claims and accusations of persons of copyright infringement. This is also determines the obligation to prove the factual circumstances.

What is generally called the burden of proof is more accurately labeled the burden of persuasion, i.e. convincing the trier of fact that the evidence produced supports the claim under the applicable evidentiary standard. Assigning the burden of proof is fundamentally important [9]. Burden of proof rules allocate the costs and risks of gathering and presenting evidence, and help filter good cases from the bad [10].

Russian legislation does not explicitly provide for the imposition of the burden of proof on any of the parties, except common procedural obligations, however, Russian Civil Code contains provisions establishing a kind of presumption of guilt of the infringer of copyright.

So, in paragraph 3 of art. 1250 states that "measures of responsibility for infringement of intellectual rights shall be applied in the presence of the fault of the infringer. $\langle\ldots\rangle$ the absence of guilt is proved by the person who violated the intellectual rights" [11]. It also provides for the application of measures of responsibility for violation in the absence of fault.

In other words, the burden of proof in copyright infringement cases in the Russian Federation can be characterized as leaning towards the presumption of the defendant's guilt, which puts the plaintiff in a more privileged procedural position. This conclusion is confirmed by numerous judicial practice, including the Supreme Court of the Russian Federation (see clause 19 of the Review of judicial practice in cases related to the resolution of disputes over the protection of intellectual rights (Approved by the Presidium of the Supreme Court of the Russian Federation on 09/23/2015; hereinafter Review), Determination of the Judicial Collegium for Civil Cases of the Supreme Court of the Russian Federation dated 02.03.2010 No. 49-B09-22; Determination of the Supreme Court of the Russian Federation No. 3055-ES-7224 dated 09/13/2016 in case No. A40-26249/2015).

At the same time, in accordance with paragraph 59 of the Review, an offense in the event of recovery of losses, the burden of proof of a civil offense is imposed on the plaintiff on the basis of the principle of "general delict" (or general rule), in which the plaintiff is obliged, guided by the provisions of Articles 15, 1252 of the Civil Code of the Russian Federation, to prove the fact and the amount of damages, as well as all the elements of the corpus delicti.

Despite the fact that in 17 U.S.C. $\S 504$ also provides for the possibility of recovering losses, it should be noted that the legal doctrines of the United States and Russia have developed somewhat different positions regarding the imposition of the burden of proof in disputes over copyright infringement.

The next issue brought up by the District Court for consideration was the determination of the possibility of causing irreparable harm in the absence of preliminary injunction.

The category of irreparable harm itself takes a special place in the US legal system. Irreparable harm is present "where, but for the grant of equitable relief, there is a substantial chance that upon final resolution of the action the parties cannot be returned to the positions they previously occupied [6].

The District Court found that irreparable harm was caused by the actions of the Defendants, since the parties did not have the opportunity to return to their original position: «It would be difficult, if not impossible, to determine how much money the Plaintiffs have lost due 
to the availability of thousands of their articles on the Defendant websites» [6].

Also, in support of this conclusion, the court indicates aspects of the "viral violation" where Elsevier's content could be transmitted and retransmitted by third parties who acquired it from the Defendants even after the Defendants' websites were shut down. Moreover, the irreparability of the damage caused is also confirmed by the fact that the amount of damage significantly exceeded the solvency of the infringer.

However, the most controversial part of the trial was the question of the presence or absence of harm to the public interest. In objections to the claim, A. Elbakyan notes that there are "lots of researchers especially in developing countries", who do not have access to key scientific papers owned by Elsevier and similar organizations, and who cannot afford to pay the high fees that Elsevier charges. The general opinion in research community is that research papers should be distributed for free (open access), not sold. And practices of such companies like Elsevier are unacceptable, because they limit distribution of knowledge.

In response, Elsevier argued that the public interest is conducive to the acceptance of the injunction and the satisfaction of the claim because it will «protect the delicate ecosystem which supports scientific research worldwide. The money Elsevier generates by selling access to scientific research is used to support new discoveries, to create new journals, and to maintain a «definitive and accurate record of scientific discovery». It also argues that allowing its articles to be widely distributed risks the spread of bad science - while Elsevier corrects and retracts articles whose conclusions are later found to be flawed, it has no way of doing so when the content is taken out of its control».

The question of the unfair structure of market relations arising around the sale of scientific works has been repeatedly raised by various lawyers. So, R. Watt claims that most academics live in a "publish or perish" environment, and so are willing to exert significant efforts in writing scientific works with the sole motivation of enhancing their hiring and promotions options, or perhaps not to see their options hampered relative to other academics. The companies that gather, revise, and publish this scientific output earn (in some cases) significant profits by providing the service upon which the academic community rides [12].

Nevertheless, the controversy that arose and even massive support for Sci-hub.org's position by the world scientific community and even universities [13] did not prevent the court from issuing a ruling to block the site, and then a decision to satisfy Elsevier's claim. Elsevier was awarded statutory damages for copyright infringement in the amount of $\$ 15.000 .000$ [5]. At the same time, the court, in its opinion, additionally noted that copyright law inherently balances two competing public interests: the rights of users and the public interest in broad accessibility of creative works, and the rights of copyright owners and the public interest in rewarding and incentivizing creative efforts (the 'owner-user balance').
The court also noted that scientific works are indeed of great public interest and it is sustained by two critical exceptions in copyright law: firstly, the «idea/expression dichotomy», secondly, the «fair use» doctrine.

Nevertheless, the court's decision today remains de facto unfulfilled, the sites Sci-hub.org and Libgen.org continued to operate using different domain names. So, in the period 2017-2018, from 300.000 to 600.000 articles were downloaded per day, which is significantly higher than the figures before 2016 [14]. In addition, in 2019, as Elbakyan said the number of visits to the site only increased and reached the mark of 1.000 .000 .000 views [15].

It is obvious that the current state of copyright in works of science is extremely unstable. Existing legal regulations cannot settle the existing actual legal relationship, all prohibitive measures do not reduce the cases of copyright infringement on scientific works in the Internet space. This legal conflict creates an atmosphere of legal skepticism, mistrust or disregard for copyright laws.

The phenomenon of scientific piracy itself, even with a large number of injunctions and peremptory norms of legislation, will not cease to exist and, moreover, will not even diminish in scale. In many ways, this is favored by the possibilities of modern information technologies, as well as the increasing desire of scientists to obtain new knowledge and share their own.

Moreover, it should be considered that the copyright policy has more than just its own legal purpose. For example, Michael W. Carroll suppose that U.S. copyright law provides a competitive advantage in the global race for innovation policy because it permits researchers to conduct computational analysis - text and data mining - on any materials to which they have access. Amendments to copyright law in Japan, and the European Union's recent addition of limitations on copyright to legalize some TDM research, implicitly acknowledge the competitive benefits provided by the fair use provision of U.S. copyright law [16] .

In this case, many lawyers agree that the institution of copyright needs reforms in terms of expanding the criteria for the fair use of works, which can be the first step in solving the problems associated with scientific piracy. In Russian civil law, a similar institution is established in Art. 1274 of the Civil Code of the Russian Federation. It is determines cases and limits of free use of the work in informational, scientific, educational or cultural purposes. However, it is noted that this institution is not sufficiently developed and studied [17].

Already now, many lawyers note the existence of significant problems in the copyright of developed countries. So, for example, Geiger C. and Izumenko E. note that the copyright of the European Union, and in particular the institution of "fair use" is «ill-adapted, fragmented, inflexible, often irrelevant and not keeping up with the technological developments» [18].

\section{Conclusion}


Thus, in modern situation, involving the massive introduction of digital technologies into science, current condition of copyright laws in developed and developing countries still has a number of significant shortcomings, which, in particular, include the problem of scientific piracy raised in the article. It should also be assumed that changes in copyright law, proposing a shift in the balance of interests in favor of the public, including the professional scientific community, will significantly help solve the accumulated problems and contradictions in this sub-branch of law.

\section{References}

1. J.H. Reichman \& R.L. Okediji, Minnesota Law Review 96(4), 1362-1480 (2012)

2. R. Vicente-Saez \& C. Martinez-Fuentes, Journal of Business Research, 88, 428-436 (2018)

3. J.M. Owen, The scientific article in the age of digitalization (Dordrecht, The Netherlands: Springer, 2007)

4. J. Bohannon Who's downloading pirated papers?

Everyone. Retrieved December 02, 2020 (2018), URL:

https://www.sciencemag.org/news/2016/04/whos-

downloading-pirated-papers-everyone(date of access:

16.03.21).

5. «Elsevier Inc. v. Sci-hub» Default Judgment - \#87 in Elsevier Inc. v. Sci-Hub (S.D.N.Y., 1:15-cv-04282).

Retrieved December 02, 2020 (2017, June 21), URL:

https://www.courtlistener.com/docket/4355308/87/elsevi er-inc-v-sci-hub/(date of access: 16.03.21).

6. «Elsevier Inc. v. Sci-hub», Opinion No. 105999 in

Elsevier Inc. v. Sci-Hub (S.D.N.Y., 1:15-cv-04282).

Retrieved December 02, 2020, (2015), URL:

https://www.courtlistener.com/docket/4355308/53/elsevi er-inc-v-sci-hub/(date of access: 16.03.21).

7. Resolution of the Plenum of the Supreme Court of the Russian Federation Dated 23.04.2019 No. 10 "On the application of part four of the Civil Code of the Russian Federation". URL:

http://www.consultant.ru/document/cons doc LAW 32 3470/c01923bc1d0db60508e82c505d7d29b544e91443/. (date of access: 16.03.21).

8. M.V. Samartseva, Courier of Kutafin Moscow State Law University (MSAL)) 6, 114-118 (2017)

9. L.P. Loren, \& A.R. Reese, Lewis and Clark Law Review, 23(2), 622-680 (2019)

10. D. Vaver, Intellectual Property Journal 23, 147-157

(2011)

11. Civil Code of the Russian Federation dated

30.11.1994 No. 51-FZ (ed. 31.07.2020) P.4. URL:

http://www.consultant.ru/documents $/$ cons doc LAW 64 629/\#dst0. (date of access: 16.03.21).

12. R. WattIntroduction, Review of Economic

Research on Copyright Issues, 7(1), 1-6 (2010)

13. A. Fox, \& J. Brainard, University of California

boycotts publishing giant Elsevier over journal costs and open access. Retrieved December 02, 2020 (2019),

URL: https:/www.sciencemag.org/news/2019/02/universitycalifornia-boycotts-publishing-giant-elsevier-overjournal-costs-and-open(date of access: 16.03.21).

14. D. Himmelstein, A. Romero, J. Levernier, T. Munro, S. McLaughlin, B. Tzovaras, \& C. Greene, Research: Sci-Hub provides access to nearly all scholarly literature. Retrieved December 02, 2020, (2018), URL:

https://elifesciences.org/articles/32822(date of access: 16.03.21).

15. Sci-Hub | Open access to scientific information Everyone sums up the year, what about Sci-Hub? Results of 2019 for Sci-Hub - a service for free reading of scientific literature. (2019), URL:

https://vk.com/wall-36928352 39093 (date of access: 16.03.21).

16. M.W. Carroll UC Davis Law Review, 53, 893-964 (2019).

17. E.V. Demyanenko, Science and education: farming and economy; entrepreneurship; law and governance, 11, 93-96 (2017)

18. C. Geiger, \& E. Izyumenko, American University International Law Review, 35(1), 1-74 (2019) 